\title{
Extent of Coterminous US Rangelands: Quantifying Implications of Differing Agency Perspectives
}

\author{
Matthew Clark Reeves ${ }^{1}$ and John E. Mitchell ${ }^{2}$ \\ Authors are ${ }^{1}$ Research Ecologist, Rocky Mountain Research Station, US Forest Service, Missoula, MT 59807, USA; and ${ }^{2}$ Rangeland Scientist Emeritus, \\ Rocky Mountain Research Station, US Forest Service, Fort Collins, CO 80526-8121, USA.
}

\begin{abstract}
Rangeland extent is an important factor for evaluating critical indicators of rangeland sustainability. Rangeland areal extent was determined for the coterminous United States in a geospatial framework by evaluating spatially explicit data from the Landscape Fire and Resource Management Planning Tools (LANDFIRE) project describing historic and current vegetative composition, average height, and average cover through the viewpoints of the Natural Resources Inventory (NRI) administered by the Natural Resources Conservation Service and the Forest Inventory and Analysis (FIA) program administered by the US Forest Service. Three types of rangelands were differentiated using the NRI definition encompassing rangelands, afforested rangelands, and transitory rangelands. Limitations in the FIA definition permitted characterization of only two rangeland types: rangeland and rangeland vegetation with a small patch size. These classes were similar to those from the NRI definition but differed in tree canopy cover threshold requirements. Estimated rangeland area resulting from the NRI- and FIA-LANDFIRE models were 268 and 207 Mha, respectively. In addition, the NRI-LANDFIRE model identified 19 Mha of afforested rangelands due principally to encroachment and increased density by species classified as trees belonging to the genera Quercus, Prosopis, and Juniperus. The biggest discrepancies between acreage estimates derived from NRI- and FIA-LANDFIRE models occurred in oak, pinyon-juniper, and mesquite woodlands. The differences in area estimates between the NRI and FIA perspectives demonstrate the need for development of unified, objective methods for determining rangeland extent that can be applied consistently to all rangelands regardless of ownership or jurisdiction. While the models and geospatial information developed here are useful for national-scale estimates of rangeland extent, they are subject to the limitations of the LANDFIRE data products.
\end{abstract}

\section{Resumen}

La extensión de los pastizales es un importante factor para evaluar indicadores críticos de la sustentabilidad de estas aéreas. La extensión aérea de los pastizales se determinó por los colindantes de Estados Unidos (US) en un marco geoespacial para evaluar espacialmente los datos explícitos del proyecto LANDFIRE describiendo su composición botánica histórica y actual, altura promedio, y cobertura promedio mediante el uso los criterios desarrollados por el Natural Resources Inventory (NRI) administrado por el Natural Resources Conservation Service y el Forest Inventory and Analysis Program (FIA) administrado por el US Forest Service. Tres tipos de pastizales se evaluaron usando la definición del NRI abarcando: pastizales, pastizales forestados y pastizales transitorios. Limitaciones en la definición de la FIA solo permiten la caracterización de dos tipos de pastizales: pastizales y vegetación con pequeñas areas de pastizal. Estas clases fueron similares a aquellas de la definición de NRI pero difirieron en los requerimientos de la cubierta aérea de los árboles. Las areas de pastizal estimadas usando los modelos NRI y FIA-LANDFIRE fueron 268 y 207 Mha, respectivamente. Además, el modelo NRI-LANDFIRE identificó 19 Mha de pastizales forestados principalmente debido a la invasión y el incremento de la densidad de especies clasificadas como arboles pertenecientes al género Quercus, Prosopis, y Juniperus. Las mayores discrepancias entre la estimación de superficie generadas por los modelos NRI y FIA-LANDFIRE se identificaron en bosques de encino, piñón-junípero y mezquite. Las diferencias entre las estimaciones de perspectivas aéreas generadas entre los modelos NRI y FIA demostraron la necesidad de desarrollar un modelo unificado; los métodos objetivos para determinar la condición de los pastizales pueden aplicarse consistentemente a todos los pastizales sin importar propiedad y jurisdicción. Mientras que los modelos e información geoespacial desarrollados aquí son útiles para la estimación a escala nacional de la condición de los pastizales, aunque están sujetas a la limitación de los productos de datos generados por LANDFIRE.

Key Words: GIS, LANDFIRE, rangeland area, rangeland classification, rangeland cover

Support was provided by USFS R\&D Resource Planning Act (RPA) Assessment funding.

Mention of a proprietary product does not constitute a guarantee or warranty of the product by the USDA or the authors and does not imply its approval to the exclusion of the other products that also may be suitable.

At the time of the research, Reeves was a research ecologist, Rocky Mountain Research Station, USDA Forest Service, Missoula, MT, USA.

Correspondence: Matt Reeves, Rocky Mountain Research Station, USDA Forest Service, PO Box 7669, 200 E Broadway, Missoula, MT 59807, USA. Email: Mreeves@fs.fed.us

Manuscript received 19 February 2011; manuscript accepted 5 August 2011.

\section{INTRODUCTION}

The debate regarding rangeland definition and identification will continue for some time and may never be solved, but quantifying the extent of US rangelands is crucial for defining key indicators of rangeland sustainability (Mitchell et al. 1999). Quantifying rangeland extent provides an area basis for estimating carbon sequestration and forage availability, serves as a baseline against which future estimates of resources can be 
Table 1. Rangeland definitions from US land management agencies with significant holdings of rangelands.

\begin{tabular}{|c|c|}
\hline gency & Definition \\
\hline $\begin{array}{l}\text { USDA Forest Service } \\
\text { (through the Forest } \\
\text { Inventory and Analysis } \\
\text { program) }{ }^{1}\end{array}$ & $\begin{array}{l}\text { Forestland: "Land that is at least } 10 \text { percent stocked by forest trees of any size (or } 5 \text { percent crown cover where stocking cannot be determined), or } \\
\text { land formerly having such treecover, and is not currently developed for a nonforest use" (USDA Forest Service 2010, p. 289). "The minimum area } \\
\text { for classification as forest land is one acre. Roadside, stream-side, and shelterbelt strips of timber must be at [sic] have a crown width at least } \\
120 \text { feet wide to qualify as forest land. Unimproved roads and trails or natural clearings in forested areas shall be classified as forest, if less than } \\
120 \text { feet in width or an acre in size. Streams and other bodies of water within forest will be considered forest land if they are less than } 1 \text { acre and } 30 \text { - } \\
\text { feet wide. Grazed woodlands, reverting fields, and pastures that are not actively maintained are included if the above qualifications are satisfied" } \\
\text { (USDA Forest Service 2010, p. 289). In addition, forested strips must be "120.0 feet wide for a continuous length of at least } 363.0 \text { feet in order to } \\
\text { meet the acre threshold" (USDA Forest Service 2010, p. 56). } \\
\text { Pasture: "Land that is currently maintained and used for grazing. Evidence of maintenance, besides the degree of grazing, includes condition of } \\
\text { fencing, presence of stock ponds, periodic brush removal, seeding, irrigation, or mowing" (USDA Forest Service 2010, p. 290). } \\
\text { Nonforest: "This is land that (1) has never supported forests (e.g., barren, alpine tundra), or (2) was formerly tree land, but has been converted to a } \\
\text { non-tree land status (e.g., cropland, improved pasture). Other examples of nonforest land are improved roads of any width, graded or otherwise } \\
\text { regularly maintained for long-term continuing use, and rights-of-way of all powerlines, pipelines, other transmission lines, and operating railroads. } \\
\text { If intermingled in forest areas, unimproved roads and nonforest strips must be at least 120-feet wide and } 1 \text { acre in size to qualify as nontree land" } \\
\text { (USDA Forest Service 2010, p. 292). } \\
\text { Rangeland: "Land primarily composed of grasses, forbs, or shrubs. This includes lands vegetated naturally or artificially to provide a plant } \\
\text { cover managed like native vegetation and does not meet the definition of pasture. The area must be at least } 1.0 \text { acre in size and } 120.0 \text { feet } \\
\text { wide" (USDA Forest Service 2010, p. 93). }\end{array}$ \\
\hline $\begin{array}{l}\text { Bureau of } \\
\text { Land Management }^{2}\end{array}$ & $\begin{array}{l}\text { Rangeland: "Land on which the indigenous vegetation (climax or natural potential) is predominantly grasses, grass-like plants, forbs, or shrubs and } \\
\text { is managed as a natural ecosystem. If plants are introduced, they are managed similarly. Rangelands include natural grasslands, savannas, } \\
\text { shrublands, many deserts, tundra, alpine communities, marshes, and wet meadows" (SRM 1998, p. 23). }\end{array}$ \\
\hline $\begin{array}{l}\text { Natural Resources } \\
\text { Conservation Service } \\
\text { (through the National } \\
\text { Resources Inventory } \\
\text { program) }\end{array}$ & $\begin{array}{l}\text { Forestland: "A land cover/use category that is at least } 10 \text { percent stocked by single-stemmed woody species of any size that will be at least } 4 \text { meters } \\
\text { (13 ft) tall at maturity. Also included is land bearing evidence of natural regeneration of tree cover (cutover forest or abandoned farmland) and not } \\
\text { currently developed for non-forest use. Ten percent stocked, when viewed from a vertical direction is a canopy cover of leaves and branches of } 25 \\
\text { percent or greater. The minimum area for classification of forest land is } 1 \text { acre, and the area must be at least } 100 \text { feet wide" (NRCS 1997). } \\
\text { Pastureland: "The land cover/use category of land managed primarily for the production of introduced forage plants for livestock grazing. } \\
\text { Pastureland cover may consist of a single species in a pure stand, a grass mixture, or a grass-legume mixture. Management usually consists } \\
\text { of cultural treatments: fertilization, weed control, reseeding, or renovation, and control of grazing. For the NRI, pastureland includes land that } \\
\text { has a vegetative cover of grasses, legumes, and/or forbs, regardless of whether it is being grazed by livestock" (NRCS 1997). } \\
\text { Rangeland: "A land cover/use category that includes land on which the climax or potential plant cover is composed principally of native grasses, } \\
\text { grass-like plants, forbs or shrubs suitable for grazing and browsing, and introduced forage species that are managed like rangeland. This would } \\
\text { include areas where introduced hardy and persistent grasses, such as crested wheatgrass, are planted and practices such as deferred grazing, } \\
\text { burning, chaining, and rotational grazing, are used with little or no chemicals/fertilizer being applied. Grasslands, savannas, many wetlands, some } \\
\text { deserts, and tundra are considered to be rangeland. Certain low forb and shrub communities, such as mesquite, chaparral, mountain shrub, and } \\
\text { pinyon-juniper, are also included as rangeland" (NRCS 1997). }\end{array}$ \\
\hline
\end{tabular}

${ }^{1}$ To be considered rangeland, a stand must first meet the nonforest criterion. In Region 5 of the US Forest Service (California and Hawaii), chaparral is not considered rangeland (US Department of Agriculture, Forest Service 2008).

${ }^{2}$ Although the BLM sometimes uses this definition, area of rangeland is not estimated using this definition, nor is it applied consistently.

compared, and is necessary for developing monitoring and management strategies (Lund 2007). Federal agencies, policymakers, and researchers have long been interested in accounting for and monitoring natural resources at regional and national scales (Nusser et al. 1998). A full accounting of area occupied by rangelands will prevent double counting during analyses aimed at defining the US land base for quantifying associated goods and services. Current estimates of US rangeland area vary widely from 161 Mha (Schuman et al. 2002) to 312 Mha (Joyce 1989). The disparate range of these figures casts skepticism on reported changes in the amount of rangeland area (Lund 2007).

Variations in area estimates are usually due to how rangelands are defined and differences in the way data are collected and presented (Mitchell and Roberts 1999). Land management agencies usually report only on lands under their jurisdiction, so identifying, compiling, and synthesizing the various estimates in a piecewise approach is prone to error and, consequently, is ineffective for identifying trends in the US rangeland base. Definitions of rangelands often include land cover, land use, and potential vegetation or administrative characteristics (Lund 2007). Each approach has unique problems (Lund 2007), none of which provide a suitable analysis platform without subjective interpretation.

Internationally, over 300 definitions have been constructed to describe rangelands (Lund 2007). The situation is no less complicated in the United States, where land management agencies do not agree on a consistent definition of rangelands. The US Department of Interior, Bureau of Land Management (BLM), has unofficially adopted the definition developed by the Society for Range Management (SRM; K. Goff, personal communication, 15 March 2008). Similarly, the US Department 
of Agriculture (USDA), US Forest Service (USFS), range management administration has also adopted the SRM definition. However, the Forest Inventory and Analysis (FIA) program has adopted yet another definition of rangelands (Table 1). The USDA Natural Resources Conservation Service (NRCS), in its National Resources Inventory (NRI; NRCS 1997), uses a longer yet similar definition to the USFS and BLM (Nusser and Goebel 1997; Table 1). These definitions share a limitation of dependence on criteria that are difficult to quantify and are sometimes applied inconsistently.

Not only are different concepts applied to identify rangelands among agencies, but different tree canopy cover thresholds are used to determine whether a site will be classified as forest or as rangeland. For example, the NRCS uses $25 \%$ tree cover to help determine if a site should be characterized as rangeland or forest, while the USFS currently uses a stocking-based definition while migrating toward a $10 \%$ canopy cover threshold. The FIA program categorizes woodlands as forest or rangeland on the basis of tree stocking. Given that pinyon-juniper woodlands occupy $21 \mathrm{Mha}$ in the western United States (Smith et al. 2004), this difference in definition is considerable. Application of these different definitions leads to disparate area estimates, making management, monitoring, and administration of US rangelands problematic.

A consistent set of spatially explicit data, describing floristic composition with appropriate precision to allow mapping of rangeland area, based on any given definition, has been lacking. Currently, there are only two data products depicting existing vegetation classes that cover the entire coterminous United States at a spatial resolution of $30 \mathrm{~m}$. These include the National Land Cover Dataset (NLCD) 2001 (Vogelman et al. 2001) and Existing Vegetation Type (EVT) from the Landscape Fire and Resource Management Planning Tools (LANDFIRE) project (Zhu et al. 2006; Rollins 2009).

Our objective was to quantify rangeland area for the coterminous United States at a spatial resolution of $30 \mathrm{~m}$ by applying both the NRI and the FIA rangeland definitions to the LANDFIRE vegetation product suite using an objective and repeatable mapping strategy applicable to large geographic areas. We chose to use the LANDFIRE product suite instead of the NLCD 2001 data set because the NLCD 2001 does not depict potential vegetation or vegetation heights that are needed to effectively apply the FIA and NRI rangeland definitions across the landscape. Moreover, the NLCD 2001 does not yield thematic resolution for suitable differentiation of woodlands from shrublands. Approaches to categorizing land cover or land use types employ both qualitative and quantitative techniques. To increase applicability and objectivity, an assessment of rangeland area should rely as much as possible on quantitative metrics, such as vegetation cover and composition. This process permits quantification of rangeland area based on vegetation composition, cover, and height from remote sensing and assumptions about historic disturbance, principally fire. We first discuss development of this mapping protocol and compare resulting area estimates derived from each analysis. Then we discuss the implications of applying different rangeland definitions offered by US land management agencies. The resulting classes are mutually exclusive, sensitive to patch size, and exhaustive (i.e., all rangeland is included regardless of ownership).

\section{METHODS}

Quantifying rangeland area using NRI and FIA perspectives required information about the height, canopy cover, vegetation composition, life form, and potential vegetation. To meet this need, the EVT, Existing Vegetation Cover (EVC), Existing Vegetation Height (EVH), and Biophysical Settings (BPS) developed by the LANDFIRE project were used (Rollins 2009).

\section{Geospatial Data Sources and Descriptions}

Differentiation of vegetation cover, height, and composition for the coterminous United States was achieved using the EVT, EVC, and EVH geospatial products, while potential natural vegetation was determined using the BPS geospatial product (Rollins 2009; http://www.landfire.gov, accessed 20 June 2011).

The EVT geospatial product consists of 398 thematic map classes that represent different terrestrial ecological systems and National Vegetation Classification System (NVCS) alliances (Grossman et al. 1998; Federal Geographic Data Committee [FGDC] 2008) for the coterminous United States. Terrestrial ecological systems represent a nationally consistent set of midscale ecological units defined by Comer et al. (2003) as "recurring groups of biological communities that are found in similar physical environments and are influenced by similar dynamic ecological processes, such as fire or flooding" (p. iv). Alliances represent a "physiognomically uniform group of plant associations sharing one or more dominant or diagnostic species" (Grossman et al. 1998, p. 23). Most areas of the coterminous United States were mapped using terrestrial ecological systems, but in some areas LANDFIRE identified and mapped a number of NVCS alliances to permit a finer level of thematic detail when the vegetation was sufficiently homogeneous on the landscape.

The LANDFIRE products depicting current vegetation were produced at a spatial resolution of $30 \mathrm{~m}$ and represent the landscape around 2001 (Reeves et al. 2009; Rollins 2009). The EVT product was created by first assigning each suitable plot in the LANDFIRE Reference Database (LFRDB; Caratti 2006) an EVT and dominant life form using a sequence table or vegetation classification key. Life form assignments of indicator species diagnostic of each EVT were obtained from the USDA NRCS Plants Database (USDA NRCS 2007). After each plot was coded with an EVT, a classification tree (Zhu et al. 2006) was used to relate field-referenced EVTs to a host of predictive variables, including satellite imagery (Enhanced Thematic Mapper and Thematic Mapper sensors) and data describing biophysical attributes of Earth's surface, such as slope, aspect, and elevation (Zhu et al. 2006).

EVC depicts nonoverlapping dominant vegetation cover for trees, shrubs, and herbs. Dominance is hierarchically assigned at each pixel beginning with tree cover. If areal coverage by a tree species is estimated at $\geq 10 \%$, the value of the pixel is represented as tree cover. If tree cover is estimated at $<10 \%$ but shrub cover is estimated at $\geq 10 \%$, then dominance is given to shrubs. Finally, if $<10 \%$ shrub cover is present, then dominance is given to herbaceous cover unless $<10 \%$ total vegetation cover is present, which is considered sparse or 
barren (Zhu et al. 2006). EVC map classes represent vegetation cover from $10 \%$ to $100 \%$ in $10 \%$ increments, yielding nine classes per life form. The EVC product was created by relating field-referenced plot data describing vegetation cover to a host of biophysical and imagery data in a similar process as for the EVT product (Zhu et al. 2006; Rollins 2009).

The final data set used to determine rangeland extent while describing current vegetation structure was EVH. The EVH product describes the average vegetation height present at each pixel in five broad thematic classes: $>0-5,>5-10,>10-25$, $>25-50$, and $>50 \mathrm{~m}$ (Rollins 2009). Creation of the EVH product commenced with quantifying the average height of vegetation at each suitable plot. These field-referenced height data were extrapolated across the landscape by relating biophysical and satellite image data to each plot using a regression tree modeling approach in a similar manner as with EVT and EVC (Zhu et al. 2006; Rollins 2009).

While EVT, EVC, and EVH represent current (around 2001) vegetation conditions, BPS represents the hypothesized dominant vegetation on the landscape prior to Euro-American settlement based on the current biophysical environment and approximations of historical disturbance regimes.

BPS map units represent not a "snapshot in time" but instead a suite of systems hosting a variety of seres within a specific biophysical environment. In a similar manner as EVT, most BPS map units are also based on the terrestrial ecological systems classification (Comer et al. 2003). This enables direct comparisons between existing (EVT) and potential (BPS) vegetation. The LANDFIRE BPS concept is similar to the concept of potential natural vegetation groups used in Schmidt et al. (2002) and the ecological site concept (Comer and Schulz 2007). Both terrestrial ecological systems and ecological sites represent a classification based on the historic plant community that existed at the time of European settlement in North America. Additionally, both systems attempt to provide insight into the historic plant community that was in dynamic equilibrium with its environment, reflecting natural disturbances such as drought, fire, flooding, and grazing. There are, however, noteworthy differences between scales of development and application of BPS and ecological sites.

There are more ecological sites described than BPS map units, resulting in a classification hierarchy where several ecological sites can nest within a single BPS. The BPS data product was developed primarily to support modeling of historic disturbance regimes and vegetation dynamics from which ecological departures can be estimated. In contrast, the greater detail and precision of ecological sites enables a more diverse suite of uses than the BPS data product, including development of site-specific management prescriptions.

The BPS data product was created in a similar fashion as the EVT, which began by first assigning a map unit (terrestrial ecological systems or NVCS alliance) to each suitable fieldreferenced plot from the LANDFIRE Reference database (Rollins 2009). This was accomplished using a sequence table relying on the presence of key species diagnostic of each system. These map units were populated across the landscape using the same suite of geospatial predictors in a regression tree process as for EVT, EVC, and EVH, with the exception of satellite imagery. Satellite imagery was necessarily excluded because its use would have inserted timber harvests and other humanmade features into the approximation of historic vegetation.

While the LANDFIRE vegetation products yield insight to current vegetation cover and composition, as well as potential historic vegetation composition (BPS), they lack the precision inherent in the various rangeland definitions. First, the NRI rangeland definition uses a $25 \%$ tree canopy cover threshold beyond which a site is sometimes not considered rangeland. When a site exhibits $>25 \%$ cover by tree species, it can sometimes qualify as rangeland provided that it meets the other rangeland criteria discussed in Table 1, such as patch size, potential vegetation, and palatability requirements. Since the LANDFIRE EVC data product depicts vegetative canopy cover in $10 \%$ increments from $10 \%$ to $100 \%$ cover, we chose to use the second class $(20-30 \%$ cover $)$ as the threshold most comparable to the NRI definition. Second, the lowest mapped canopy cover in the EVC product is $10 \%$, making it impossible to identify sites corresponding to the USFS woodland canopy cover threshold of 5\% (USDA Forest Service FIA 2007). As a result, the lowest tree canopy cover class (10-19\%) was chosen to identify and remove woodland types that would not be classified as rangeland according to the USFS rangeland definition. Third, the LANDFIRE EVH data product depicts average vegetative height of dominant vegetation in relatively broad thematic classes. Since the NRI rangeland definition uses a 4-m threshold (USDA NRCS 1997) to determine whether an individual is a tree or shrub for some species (crossover type, defined below), we considered anything greater than $5 \mathrm{~m}$ to be a tree if it was a crossover type. This was necessary because the lowest class in the LANDFIRE EVH product is $0-5 \mathrm{~m}$. Fourth, the NRI definition requires identification of the life form most representative of the site being evaluated to determine if it should be considered rangeland. In most cases the process is straightforward, but some species in the NRCS Plants Database can be classified as either tree or shrub (crossover species). In addition, the EVT data product indicates not dominant species but rather a terrestrial ecological system or NVCS alliance in which several species could be present. Thus, at each pixel, dominant species and life form had to be estimated. Estimation of the most likely dominant species associated with each EVT was accomplished by analyzing 312871 plots in the LFRDB and computing the frequency for dominant species and, therefore, the life form for each EVT. From this analysis, spatially explicit data depicting the dominant life form and most likely dominant species for the entire coterminous United States were created. EVTs dominated by crossover species (Table 2) were identified for further analysis since they can be classified as either tree dominated or shrub dominated, depending on the average height of the vegetation. All terrestrial ecological systems, including these crossover types, combined with the other vegetation data products were evaluated in two geospatial models, each corresponding to either the NRI or the FIA rangeland definitions to quantify rangeland area.

\section{Rangeland Extent Quantified Using NRI Definition}

The first model (NRI-LANDFIRE) estimated rangeland area from the viewpoint of the NRI rangeland definition (Fig. 1). The NRI-LANDFIRE model estimates area of three rangeland 
Table 2. Ten LANDFIRE Existing Vegetation Type (EVT) classes with the greatest areal coverage that are dominated by "crossover species" or those species that can be either shrub or tree life form according to the National Resources Conservation Service Plants Database, depending on the height of the individual. Also listed are the dominant species in each EVT that make it a crossover type estimated from the LANDFIRE Reference Database (Caratti 2006). Species frequency is listed for only the most dominant (frequent) species in each EVT.

\begin{tabular}{|c|c|c|c|c|}
\hline LANDFIRE Existing Vegetation Type & $\begin{array}{c}\text { Estimated coverage in coterminous } \\
\text { United States (ha) }\end{array}$ & $\begin{array}{l}\text { Dominant crossover } \\
\text { species }\end{array}$ & $\begin{array}{l}n \text { (no. of plots associated } \\
\text { with each EVT) }\end{array}$ & Frequency (\%) \\
\hline \multicolumn{5}{|l|}{ Eastern Great Plains Mesquite } \\
\hline Woodland and Shrubland & 7051817 & Prosopis glandulosa & 138 & 93 \\
\hline \multicolumn{5}{|l|}{ Apacherian-Chihuahuan } \\
\hline Mesquite Upland Scrub & 6730604 & P. glandulosa & 874 & 35 \\
\hline Edwards Plateau Limestone Shrubland & 4138206 & Juniperus ashei & 87 & 92 \\
\hline Tamaulipan Mesquite Upland Scrub & 3457349 & P. glandulosa & 47 & 96 \\
\hline Madrean Pinyon-Juniper Woodland & 1787265 & Juniperus deppeana & 911 & 11 \\
\hline Quercus gambelii Shrubland Alliance & 1240967 & Quercus gambelii & 1078 & 85 \\
\hline \multicolumn{5}{|l|}{ Southern Rocky Mountain } \\
\hline Pinyon-Juniper Woodland & 1235285 & Juniperus monosperma & 1191 & 26 \\
\hline California Mesic Chaparral & 1219595 & Quercus dumosa & 1636 & 10 \\
\hline California Montane Riparian Systems & 688512 & Salix lasiolepis & 815 & 6 \\
\hline \multicolumn{5}{|l|}{ Central and Southern California Mixed } \\
\hline Evergreen Woodland & 646133 & Quercus agrifolia & 311 & 13 \\
\hline
\end{tabular}

classes, including rangelands, afforested rangelands, and transitory rangelands (Spreitzer 1985). Rangelands fully meet each criterion contained within the NRI definition. Rangelands are dominated by shrub or herbaceous vegetation both currently and historically. Further, the site must meet the minimum size restrictions (discussed below) and contain species suitable for browsing or grazing. Although the provision for browsing or grazing suitability is ambiguous, here we assume that it refers to the relative degree of palatability and nutritional quality relative to forage consumed by domestic or wild herbivores. Afforested rangelands, as defined here, represent sites on which the potential vegetation is dominated by herbaceous or shrub species but currently support $>25 \%$ tree cover (i.e., encroachment or afforestation). Transitory rangelands, as defined here, represent sites currently dominated by herbs or shrubs, but the potential vegetation is classified as forestland capable of usually supporting $>25 \%$ tree cover. Conversely, if a site was dominated by trees exhibiting $>25 \%$ cover and the potential vegetation supports $>25 \%$ cover, it is considered to be nonrangeland (Fig. 1). As with rangelands, both afforested and transitory rangelands were subject to size and grazing or browsing suitability conditions. All three categories of rangelands were identified using a series of steps in the NRI-LANDFIRE.

The first step in the NRI-LANDFIRE model was determination of the dominant life form present at each pixel, which, in turn required knowledge of the dominant species (Fig. 1). If the dominant species at a pixel was herb, shrub, or tree, then the process moved to the second step. If, however, the dominant species present at a pixel was a crossover species (i.e., the species can be either tree or shrub, depending on height), the height of the vegetation was evaluated to determine if it should be considered shrub or tree dominated. If the average vegetation height at a site dominated by crossover species was $<5 \mathrm{~m}$, the life form was considered to be shrub. If the dominant species was not a crossover species, no evaluation of height was needed. Once the dominant life form at a pixel was determined, the site being evaluated was passed to the second step in the model.

The second step in the NRI-LANDFIRE model, necessary only if the dominant species was a tree, evaluated tree canopy cover. The NRI rangeland perspective permits up to $25 \%$ cover of trees provided that the area meets the patch size, potential vegetation, and palatability requirements in the rangeland definition. The third step was estimating the potential vegetation at a pixel. If current tree canopy cover exceeded $25 \%$ but potential vegetation was herb or shrub dominated and belonged to a site exceeding the minimum size threshold, the pixel was considered to be afforested rangeland. If, however, tree cover exceeded $25 \%$ and potential vegetation was tree dominated, the pixel was considered to be nonrangeland and not retained for further analysis. If a site was dominated by shrub or herb vegetation but potential vegetation was tree dominated, the pixel was considered to be transitory rangeland and retained for further analysis.

The final step in the NRI-LANDFIRE was evaluating the potential pool of rangeland pixels by computing the patch size that each pixel belonged to. To accomplish this task, the pool of possible rangeland pixels was processed using two consecutive majority filters (ESRI, ArcGIS Version 9.3), reducing noise in some areas. Following the majority filter, the pixels were consolidated into individual regions (or sites). These regions were subsequently converted from raster to vector data formats, enabling area to be calculated. The NRI definition permits classification of rangeland on patches $\geq 0.4048$ ha with a 33-m width (USDA NRCS 1997). Because of processing constraints, however, a 2-ha (4.94-ac) minimum size restriction was imposed, and the minimum width restriction was not used. After the current vegetation, potential vegetation, canopy cover, and patch size were evaluated, each pixel was assigned to one of the three rangeland or two nonrangeland classifications (Fig. 1). Estimates of total rangeland area for the coterminous US rangeland categories included rangelands and afforested rangelands. Although the GIS model identified and 


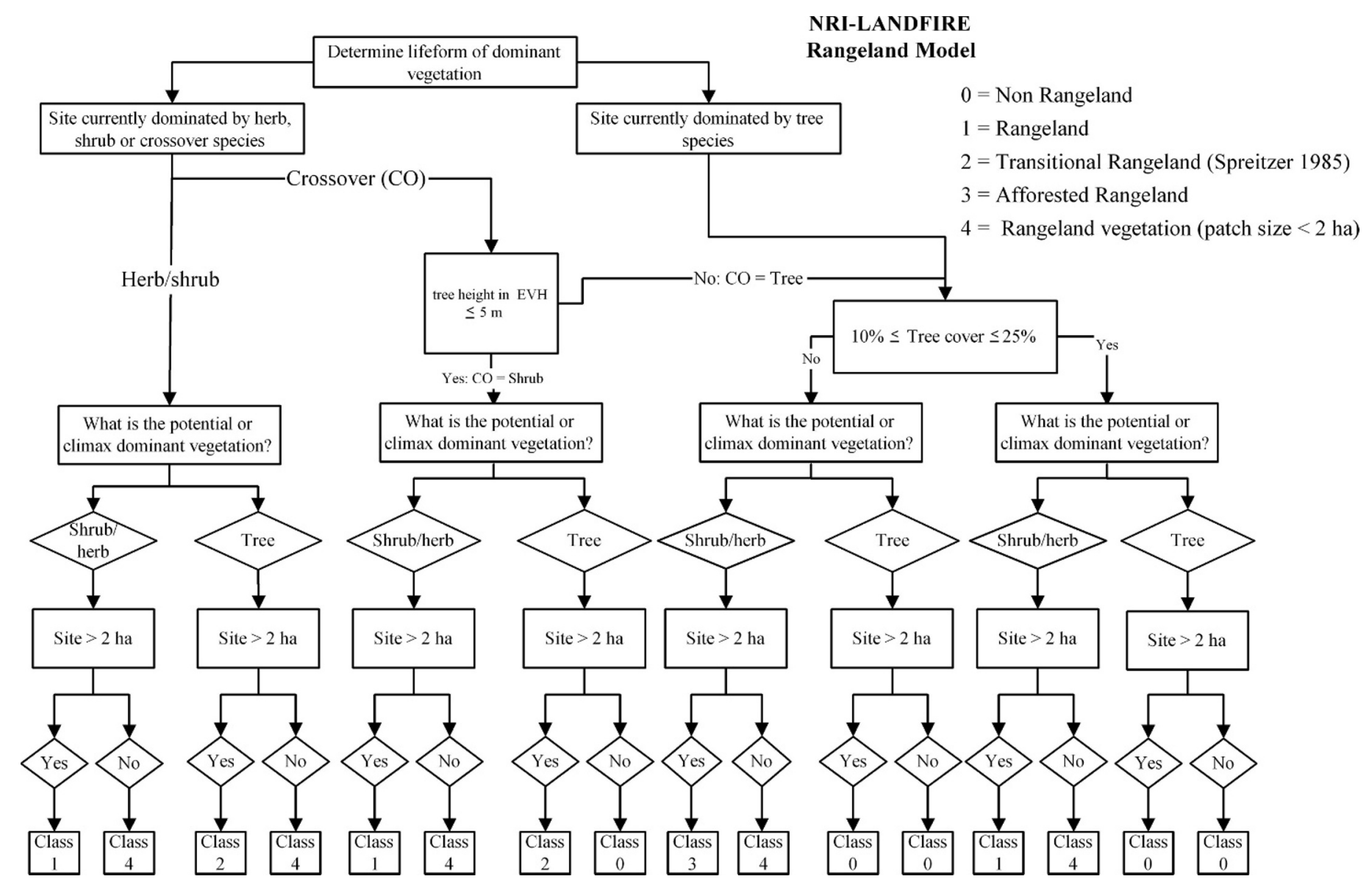

Figure 1. Program flow of the National Resources Inventory (NRI)-Landscape Fire and Resource Management Planning Tools (LANDFIRE) GIS model. The NRI model is more intricate reflecting the greater specificity of rangeland components in the NRI definition. Crossover species (CO) are those that can be classified as either trees or shrubs depending on the height of the individual (or average site condition).

differentiated transitional rangelands, they were not included in the final area estimate because, although these rangeland types can be an important source of forage for domestic and wild ungulates, they typically occur on historically forested sites and do not qualify as rangelands under the NRI rangeland definition. Similarly, areas dominated by herbaceous or shrubby vegetation existing on patches $<2$ ha were not included in the final area tally because they do not qualify as rangelands under the NRI rangeland definition, given our computational limitations.

\section{Rangeland Extent Quantified Using FIA Definition}

The second model developed to quantify rangeland extent was the simpler FIA-LANDFIRE, which yielded only one rangeland class. The FIA-LANDFIRE model required less information than the NRI-LANDFIRE (Table 1). The components needed to quantify the extent of rangelands using the FIA rangeland definition were EVT, EVC, and BPS. Although this definition does not reference potential or historic vegetation, in order to be classified as rangeland, a site must first be characterized as nonforest. In general, a site will not be classified as nonforest unless it is and has been largely devoid of trees. One major exception to this rule is that nonforest status can be achieved even when trees are present in significant quantity provided that the site has been developed for a nonforest use (USDA
Forest Service 2007), though the mere presence of livestock does not constitute nonforest use.

Detecting nonforest use was not possible in the current work, which focused on vegetation structure and composition estimated from remote sensing. Determining if a site usually supported forests in the past, thereby removing it from rangeland consideration, required analysis of the BPS data product. Each BPS was classified, as with the NRI-LANDFIRE model, as being either forested or nonforested based on disturbance regimes and floristic composition. An assumed $10 \%$ tree canopy cover threshold (corresponding to the current canopy cover requirement for existing vegetation to be classified as forest; Bechtold and Patterson 2005) (Table 1) was used to decide if a BPS was historically dominated by tree life forms. This assumption was more restrictive than the $25 \%$ requirement defined by the NRI-LANDFIRE model, resulting in a smaller number of BPS map units qualifying as rangeland.

Forests identified by the FIA-LANDFIRE rangeland model were subsequently removed from further analysis. If a site is currently or was historically occupied by $\geq 10 \%$ cover by trees of any size, it is usually considered forestland. As mentioned before, thresholds of $10 \%$ and $5 \%$ canopy cover are often used as proxies for stocking rates to define forestland and woodlands, but the FIA program is considering adopting canopy cover as an identifier of forest lands in lieu of stocking 


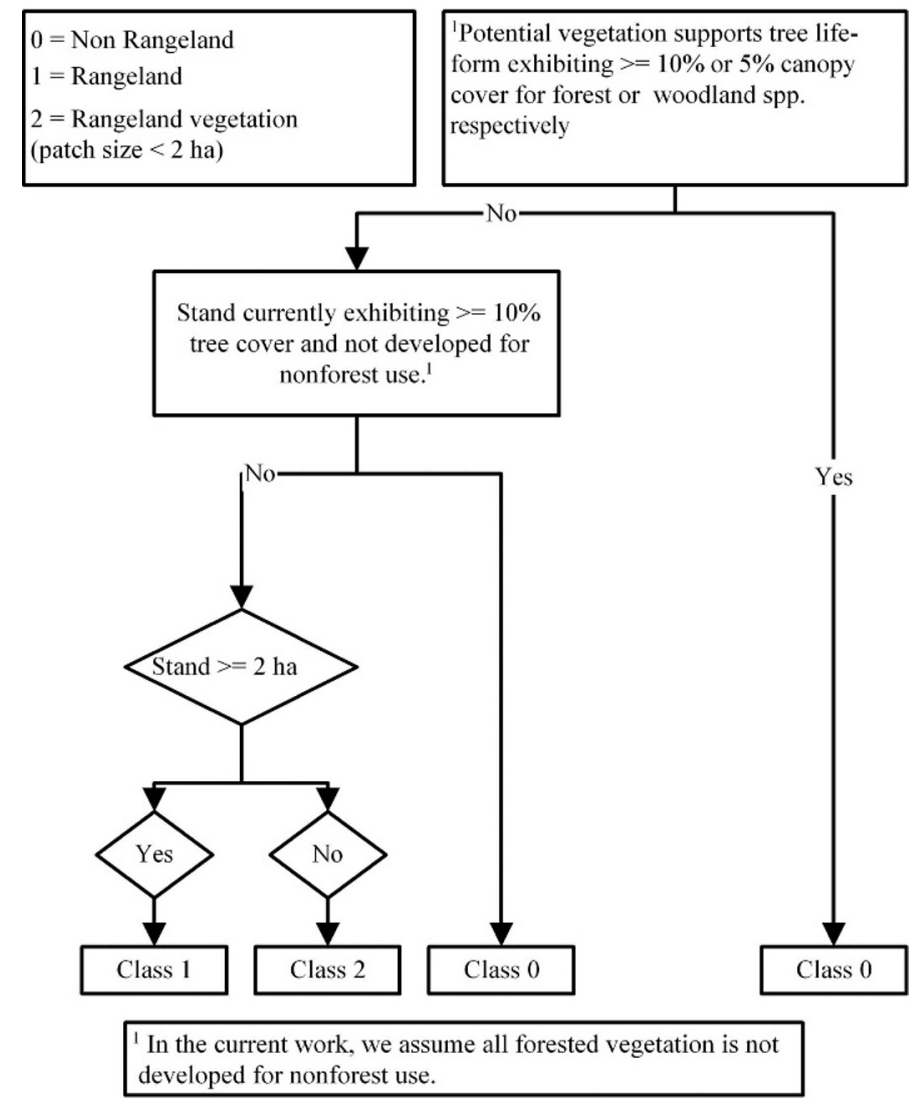

Figure 2. Program flow of the Forest Inventory and Analysis (FIA)Landscape Fire and Resource Management Planning Tools (LANDFIRE) GIS model. This model does not include the crossover species (CO) evaluation present in the NRI-LANDFIRE model because the FIA forest definition states that a forest is "land that is at least 10 percent stocked by forest trees of any size" (US Department of Agriculture, Forest Service 2010, p. 289). Thus, the designation of forestland is based on the presence of tree species so size is not a consideration.

rate (G. Moisen, personal communication, 18 April 2009). Therefore, any current site exhibiting $\geq 10 \%$ tree canopy cover was excluded from further analysis. This was accomplished using the lowest tree canopy cover value in the EVC product (10-19\%; Fig. 2). Once all current or potentially forested landscapes were removed from further analysis, the remaining pixels were evaluated against the minimum mapping unit exactly as in the NRI-LANDFIRE model.

Estimates of total rangeland area for the coterminous United States resulting from the FIA-LANDFIRE model were computed by summing the area of pixels corresponding to the "rangeland" category. Although the GIS model identified and differentiated areas dominated by herbaceous or shrubby vegetation existing on patches $<2$ ha, these small patches were not included in the final area tally because they do not qualify as rangelands under the FIA rangeland definition because of patch size and our computational limitations.

\section{RESULTS AND DISCUSSION}

\section{Rangeland Extent}

The assessment results and model formulations highlight differences between two agency perspectives and indicate the magnitude and spatial arrangement of these differences across the landscape. The geospatial models using the NRI and FIA perspectives resulted in area estimates for coterminous US rangelands of 268 Mha and 207 Mha, respectively (Fig. 3). Assuming that Alaska contains roughly $70 \mathrm{Mha}$ of rangeland (Joyce 1989) reveals that US-wide estimates from the NRI and FIA perspectives of 338 Mha and 277 Mha, respectively.

The estimate based on the NRI perspective differs by only $7.7 \%$ from previous US rangeland area estimates of $312 \mathrm{Mha}$ (Joyce 1989), while the FIA perspective resulted in an $11 \%$ difference. The biggest discrepancies in rangeland area estimates derived using NRI and FIA perspectives occur in oak, pinyon-juniper, and mesquite woodlands (Fig. 4).

These discrepancies reflect the different treatment of some woodland species and the differing canopy cover thresholds in FIA and NRI rangeland definitions. Woodlands are typically dominated by crossover species, such as Juniperus deppeana and Prosopis glandulosa, which often create a rangeland designation from the NRI perspective but not the FIA. Another area of discrepancy between the NRI- and FIA-LANDFIRE model estimates exists in the southeastern United States (Fig. 4), particularly in forested flatwoods and former Pinus palustris (longleaf pine) savannah sites. While these sites can be successful timber production areas, many developed under a frequent (1-5-yr return interval) summer fire regime (USDA Soil Conservation Service 1981). This fire regime suppressed most tree growth, creating a savannah ecosystem postulated to support a sparse tree canopy exhibiting less than $25 \%$ cover. The difference in treatment of woodlands and some forests between the FIA and NRI programs guarantees that rangeland area estimates emanating from these programs cannot be harmonized given current differences. As a rule, most woodland species are considered tally species (USDA Forest Service FIA 2010), meaning that they are measured during the sampling event, and therefore they count toward forest or woodland area estimates.

\section{Afforestation}

One of the unique aspects of this study is the systematic quantification of the extent of afforestation on US rangelands, depicted herein as "afforested rangelands." Afforestation, or encroachment by tall shrubs and trees on rangelands, can have significant ecological consequences for ecosystem structure and function. Carbon cycling (Knapp et al. 2008; Nafus et al. 2008), forage production (Burkinshaw and Bork 2009), fire regimes, and fire behavior (Roth et al. 2010) can all change as a result of afforestation. Afforested rangelands, as defined here, represent areas postulated to support $<25 \%$ tree canopy cover historically but are currently occupied by trees having a canopy cover exceeding this threshold.

The afforestation analysis excludes evaluation of woody encroachment by shrubs because, by definition, this encroachment does not remove the site from a rangeland category. Hence, the term "afforested rangeland" is preferred in this study to indicate the focus of the analysis on increasing density of tree species. Only the NRI definition of rangelands permitted this in our study because the FIA definition of forests and woodlands does not usually allow sites historically or currently dominated by trees to be classified as rangeland. The USDA 

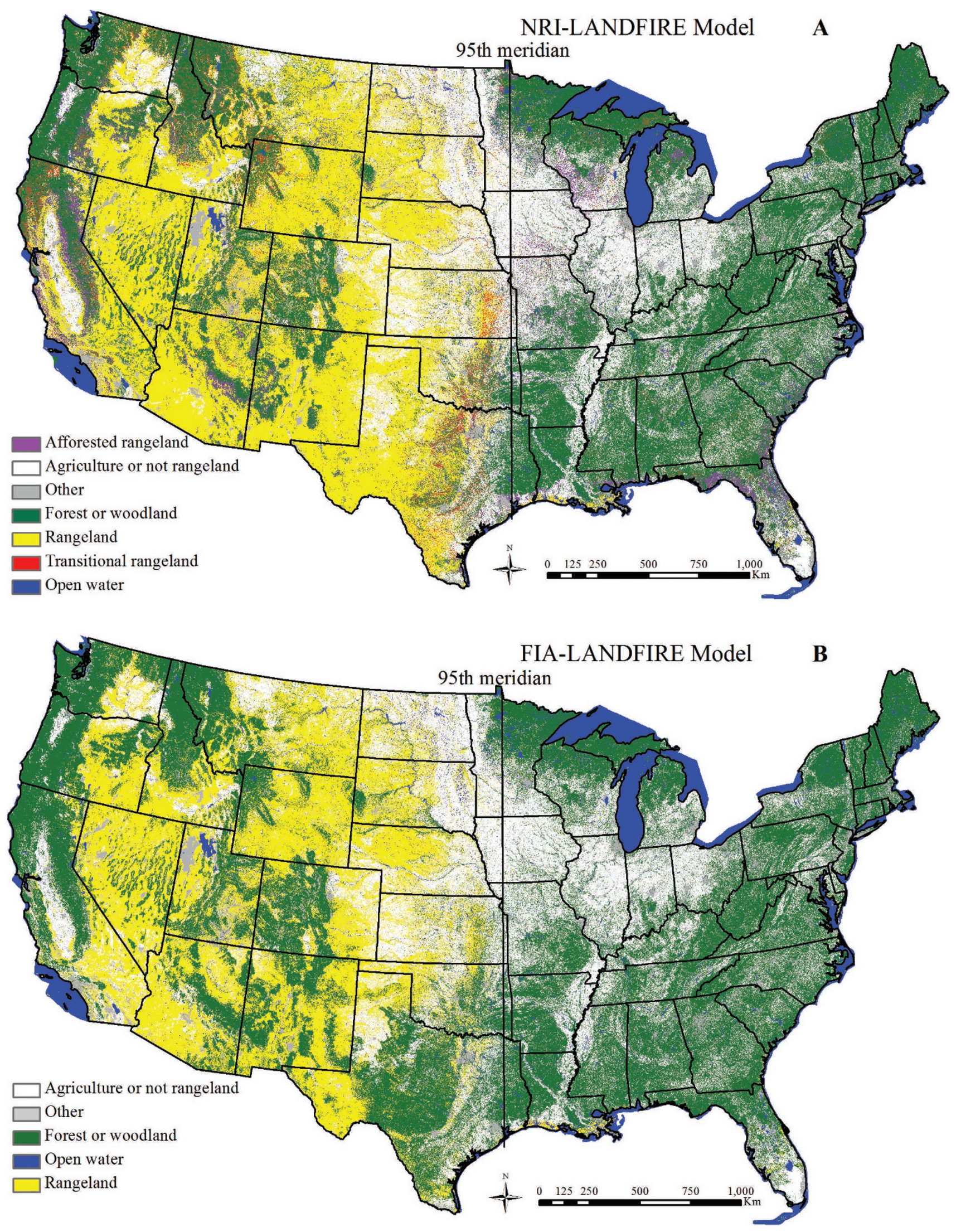

Figure 3. Results of the National Resources Inventory (NRI)- and Forest Inventory and Analysis (FIA)-Landscape Fire and Resource Management Planning Tools (LANDFIRE) models identifying rangelands in the coterminous United States. The NRI-LANDFIRE model (A) produces more map classes than the FIA-LANDFIRE model (B) because of the relative intricacy of the NRI rangeland definition. Transitional rangelands are not included in the rangeland area tally. 


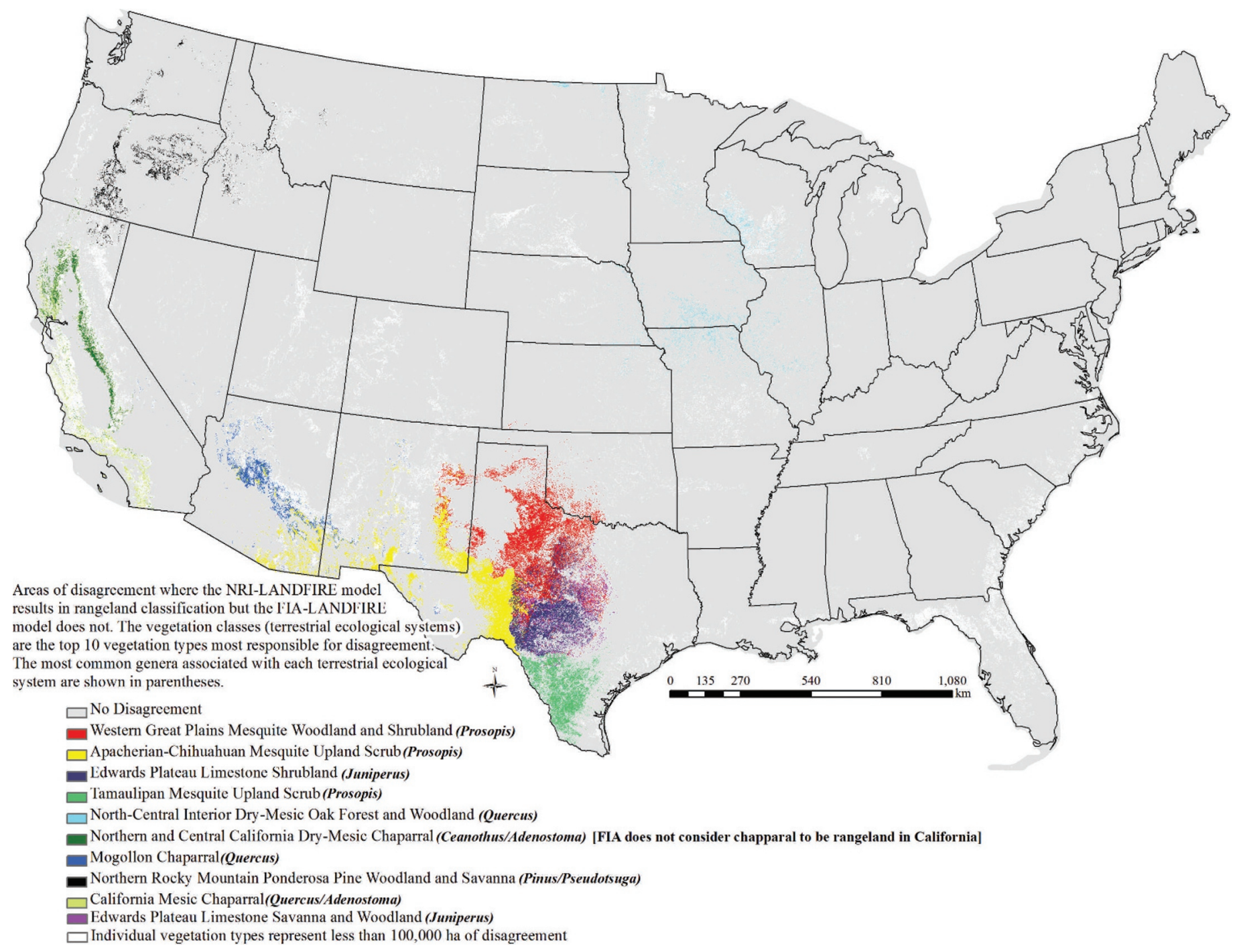

Figure 4. Areas of disagreement in rangeland extent between the National Resources Inventory (NRI)- and Forest Inventory and Analysis (FIA)Landscape Fire and Resource Management Planning Tools (LANDFIRE) models. Areas of disagreement generally reflect different tree canopy cover thresholds and treatment of woodland species (such as Juniperus, Quercus, and Prosopis spp.) between the NRI and FIA rangeland definitions.

Forest Service (2007) defines nonforest land as "land that does not support, or has never supported forests" (p. 212). Thus, if a site has or previously exhibited tree cover exceeding $10 \%$ (or $5 \%$ in the case of woodland species), it cannot be nonforest, ensuring that it will not achieve rangeland status.

The amount of area estimated to be afforested by tree species using the NRI-LANDFIRE model is 19 Mha. Figure 5 depicts the areas where afforestation has likely occurred in rangelands across the coterminous United States.

The terrestrial ecological systems and NVCS alliances with the greatest amount of afforestation are shown in Table 3. The Northern Rocky Mountain Ponderosa Pine Woodland and Savanna BPS exhibits the greatest estimated afforested area. The most common species responsible for afforestation belong to the genera Pinus, Quercus, Prosopis, and Juniperus. Increases in species belonging to these genera probably reflect changes in disturbance regimes since the presettlement era. These results must be interpreted carefully because the genera listed in Table 3 are only a fraction of the full suite of tree species that are becoming denser on rangeland sites. Only the most frequent genera associated with the most common EVTs causing afforestation are listed.

The results indicate the estimated extent and spatial arrangement of afforested rangelands. This afforestation modeling process outlined here is useful because it provides an analytical framework from which landscape-scale restoration opportunities can be identified. The modeling results might be improved, however, using more site-specific data, such as ecological sites.

\section{Limitations of the Assessment}

Despite the novel approach to quantifying rangeland area described here, ambiguities, inconsistencies, and assumptions are still present among definitions, data, and model logic, leading to limitations and potential sources of error associated with rangeland area estimates.

Data Limitations. Determining the extent to which each ecosystem supported tree species is based on knowledge of and assumptions about past disturbance regimes, both of which are 


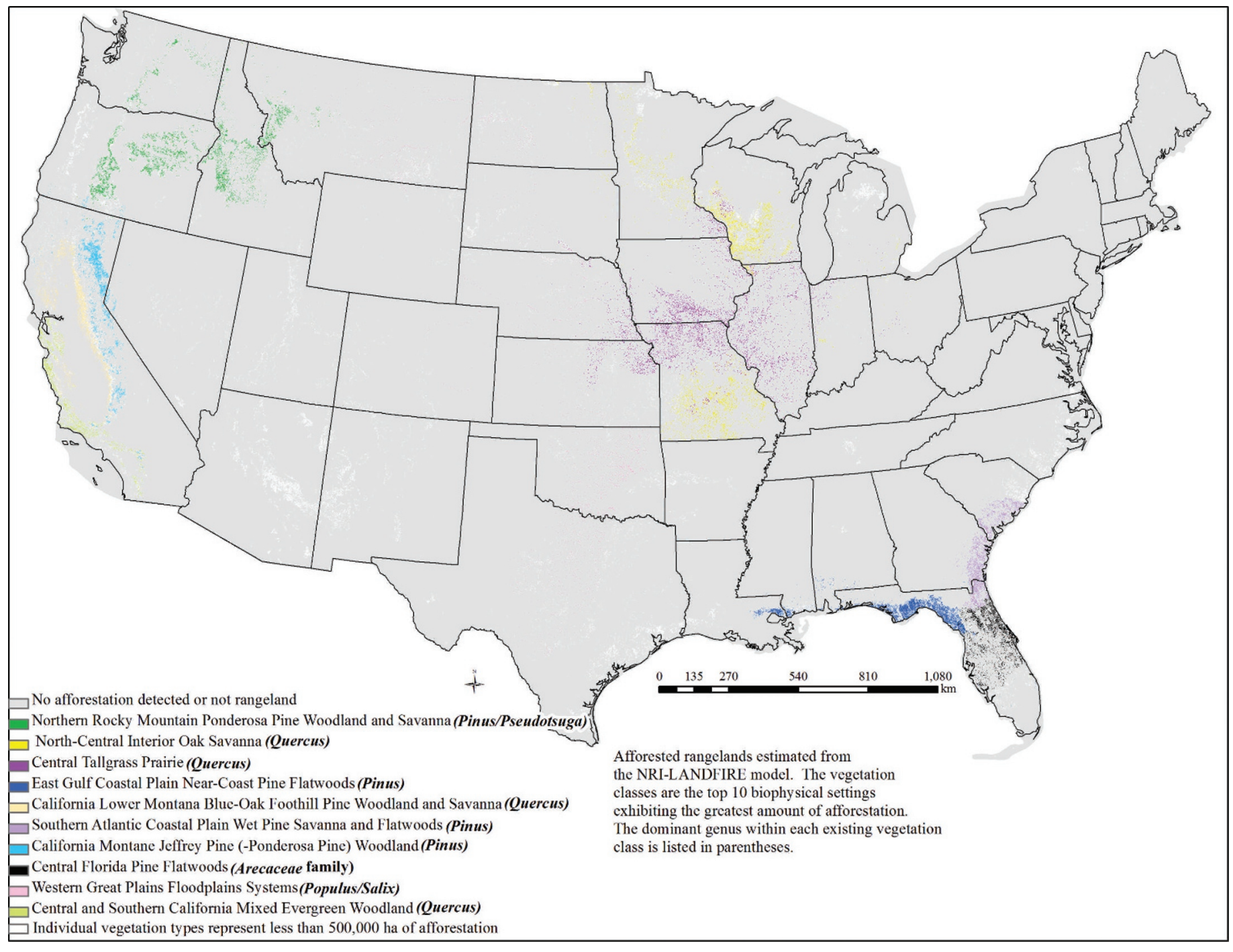

Figure 5. Estimated areas of afforested rangelands identified using the National Resources Inventory (NRI)-Landscape Fire and Resource Management Planning Tools (LANDFIRE) model. Only the top 10 Biophysical Settings types exhibiting the greatest amount of afforestation are differentiated. This level of detail was not available with the Forest Inventory and Analysis (FIA)-LANDFIRE because, by definition, if a site is occupied by trees, then it will receive a forest or woodland classification and usually cannot be considered rangeland.

subject to error. Many of the analysis techniques used here are subject to data inaccuracies and other inherent limitations of the LANDFIRE vegetation data products. The satellite imagery used in their creation span a period from 1999 to 2003 (Reeves et al. 2009), and therefore the LANDFIRE existing vegetation data depict landscape conditions around 2001 (the thematic accuracy of LANDFIRE EVT data can be found at (http:// www.landfire.gov/dp_quality_assessment.php, accessed 10 June 2010). Accuracies of nonforest EVTs range from 0\% user accuracy in Rocky Mountain Lower Montane-Foothill Shrubland (only nine plots of this type out of approximately 312871 were available for analysis) to over $90 \%$ for Colorado Plateau Pinyon-Juniper Woodland and some ponderosa pine types.

Determining if a site was historically considered rangeland using either the NRI or FIA definition required only knowledge of life form dominance and an estimated historic average cover by tree species. Overall, the users' accuracy of forest and woodland life form assessment was 87\% (http://www.landfire. gov/documents_dataquality.php, accessed 1 September 2010), which is clearly suitable for distinguishing forests from nonforest systems. In addition to accuracy considerations, there is an inherent mismatch between field-referenced estimates of species composition and those derived from remote sensing techniques. In this case, terrestrial ecological systems and alliances from the NVCS hierarchy were used, which do not always indicate precisely what species are present at a given site. This was usually not a critical factor since the dominant life form of the site was most commonly evaluated. However, in the case of crossover species, knowing the life form required knowledge of specific species and their associated heights. Thus, we necessarily inferred species composition based on the database analyses described above and assigned life form based on height.

In a similar manner as EVT, use of the BPS data product to describe potential vegetation relied on assumptions. The major assumption was that using BPS as the descriptor of a site adequately estimated the historic vegetation composition and structure. While this assumption may not be valid at the pixel 
Table 3. Ten rangeland Biophysical Settings (BPS) with the greatest area of current afforestation and the dominant genus or family most likely to be responsible for the afforestation estimated from the Landscape Fire and Resource Management Planning Tools (LANDFIRE) Reference Database (Caratti 2006). See Figure 5 for distribution of these BPS types.

\begin{tabular}{lll}
\hline \multicolumn{1}{c}{ Biophysical Settings } & $\begin{array}{l}\text { Dominant genus or family } \\
\text { causing most afforestation }\end{array}$ & $\begin{array}{c}\text { Estimated afforested area in } \\
\text { coterminous United States (ha) }\end{array}$ \\
\hline $\begin{array}{l}\text { Northern Rocky Mountain Ponderosa } \\
\text { Pine Woodland and Savanna }\end{array}$ & Pseudotsuga/Pinus ${ }^{1}$ & 1800000 \\
North-Central Interior Oak Savanna & Quercus & 1700000 \\
Central Tallgrass Prairie & Quercus & 1600000 \\
East Gulf Coastal Plain Near-Coast Pine Flatwoods & Pinus & 1000000 \\
California Lower Montane Blue Oak-Foothill & & 940000 \\
$\quad$ Pine Woodland and Savanna & Quercus & 890000 \\
Southern Atlantic Coastal Plain Wet Pine Savanna and Flatwoods & Pinus & 843000 \\
California Montane Jeffrey Pine (Ponderosa Pine) Woodland & Pinus & 712000 \\
Central Florida Pine Flatwoods & Arecaceae family & 678000 \\
Western Great Plains Floodplain Systems & Populus/Salix ${ }^{2}$ & 630000 \\
Central and Southern California Mixed Evergreen Woodland & Quercus & \\
\hline
\end{tabular}

${ }^{1}$ Both Pseudotsuga and Pinus were equally dominant.

${ }^{2}$ Both Populus and Salix were equally dominant.

level $\left(30 \mathrm{~m}^{2}\right)$, it was probably suitable for regional and national assessments of rangeland. In the future, using ecological sites to evaluate past disturbance regimes and species composition may improve results reported on here.

The final data consideration in this study regards the mapping and characterization of pasturelands. All pastures were excluded from the rangeland area analysis. The location of pastures was determined from the LANDFIRE EVT data product. Pastures are not considered rangelands using either the NRI or the FIA definition and should not contribute to the estimated extent of US rangelands. The identification of pastures in this project, however, is totally dependent on remote sensing, and therefore the estimates of rangeland area will be affected by the accuracy of that thematic class. Confusion could exist between rangeland and pastureland in a remote sensing analysis of land cover. The vast majority of pasturelands, however, occur in the eastern United States, and therefore most of these lands would not add to the estimated rangeland area anyway because of historically high cover by tree species.

Rangeland Definitions and Agency Sponsored Data Collection. There are difficulties interpreting the rangeland definitions presented by the FIA and NRI programs. The NRI (USDA NRCS 1997) definition indicates "climax or potential" (chap. 2, p. 2), and the difference between these two concepts could change the estimation of rangeland extent, depending on interpretation. If, for example, the climax concept was used (interpreted here as succession in the absence of disturbance), many of the pinyon-juniper woodlands would no longer be considered rangelands because some sites clearly support an abundance of tree species from a climatic perspective, which historically were not present in the site (because of factors such as historic fire regime and differing environmental conditions in the past). The situation is further complicated by a lack of agreement over whether pinyon-juniperdominated communities represent a successional endpoint or a seral state resulting from disturbance factors, such as grazing, fire, and climatic variations (Archer et al. 2001; Shinneman and Baker 2009).
In a similar fashion, the NRI rangeland definition (USDA NRCS 1997) further stipulates "suitable for grazing and browsing" (chap. 2, p. 2). This begs the question, "Suitable for grazing or browsing by what?" In the present study, this point was treated rather liberally, including domesticated and wild herbivores. The only terrestrial ecological system dominated by herbs or shrubs that was deemed unsuitable for all herbivory and thus not included as rangeland was the South Florida Everglades Sawgrass Marsh (Comer et al. 2003). This system is characterized by sites dominated by Cladium mariscus ssp. Jamaicense (sawgrass), a species generally considered too unpalatable to be grazed by livestock (Steward and Ornes 1975). Moreover, the inundated nature of the South Florida Everglades provides a relatively unsuitable environment for grazing. In addition to difficulties interpreting all rangeland definition components, there appear to be some subtle inconsistencies in data collection within the FIA program.

Each FIA region may have slightly different protocols in the case of non-"core" species (USDA Forest Service 2010), making it difficult to broadly characterize rangelands in a consistent manner. For example, species such as Acer glabrum, Acer platinoides, Acer grandidentatum, and Celtis reticulata can possibly be measured as tally trees by some FIA units but not by others, potentially resulting in differences in tree canopy cover due to measurement protocol. This means that coding terrestrial ecological systems where these species are found as being tree dominated from an FIA perspective is ambiguous. In addition, chaparral is not considered rangeland in Region 5 (California and Hawaii) of the USFS. Chaparral in Region 5 occurs throughout Mediterranean California and is differentiated from Mogollon chaparral (Comer et al. 2003), or inland chaparral, which does appear to be considered rangeland through the FIA perspective. Consistent treatment of each species and vegetation types in the FIA protocol may help alleviate this problem. Similarly, the manner in which land management agencies report rangeland area is critical for understating comparisons made between the current study and published rangeland estimates. 
Federal land management agencies use different methods that have not been consistent through time and at different spatial scales (Mitchell 2000) for determining rangeland area. In general, rangeland area is determined in the USFS National Forest System as area of land within grazing allotments having range management objectives (Mitchell 2000), thus propagating errors of both commission and omission of rangeland types.

The FIA program cannot be considered a reliable source for taking census of rangelands because the sampling protocol, by design, can exclude nonforested plots from analysis (USDA Forest Service 2007). In a similar fashion, the BLM reports rangeland area as all lands within grazing allotments regardless of the land cover present. Again, this omits lands outside of grazing allotments and includes forested sites in the rangeland area estimates. Finally, while the NRI definition is the most complete and succinct of federal land management agencies, rangeland area estimates derived by the NRCS are limited to nonfederal lands.

Land cover statistics derived from remotely sensed data, such as those presented here, should be validated by ground-based data whenever possible (Hunt et al. 2003). National, plotbased sampling systems such as FIA are expected to slowly expand onto nonforested lands to help accomplish this goal. Similarly, the NRI rangeland evaluation process could also be expanded to include federal lands. Advances in database management will help provide the technology for doing this; however, the legal, administrative, and social aspects of the issue, including agency cultures, are problematic.

\section{IMPLICATIONS}

While the approach developed here and resulting data will not end the debate over what constitutes a rangeland, there are several significant implications of the work. First, the models and resulting data may provide impetus for land management agencies to agree on common evaluation techniques, especially as they move toward interagency collaboration (Knight and Landres 1998). Since it is unlikely that a common rangeland definition will be adopted among agencies, a method to monitor rangeland extent regardless of definitions, such as that developed here, could be adopted. Perhaps the rangeland area estimates published here will inspire agencies to develop assessment techniques enabling rebuttal or validation of these results.

The approach developed here provides a basis for extensively quantifying at least three critical indicators of rangeland sustainability (Joyce et al. 2000): rangeland area by plant community, area of rangeland under conservation ownership, and fragmentation of rangeland and rangeland plant communities. Application of this approach may be especially beneficial to inform mitigation and adaptation strategies for dealing with climate change and associated impacts through monitoring of rangeland extent. Finally, in addition to being useful for quantifying indicators of rangeland sustainability, the data derived from this study provide exhaustive coverage for the coterminous United States that can be used to inform new projects aimed at evaluating such phenomena as carbon sequestration on rangelands. Any project seeking to isolate rangelands for ecological model applications may benefit from this study. Without a spatial analysis mask, such as that derived here, the possibility of double counting or overestimating ecological processes, such as carbon sequestration, rises considerably.

\section{ACKNOWLEDGMENTS}

The authors acknowledge Donald Long, Rocky Mountain Research Station, Fire Sciences Laboratory, and Chris Toney, Rocky Mountain Research Station, Forest Inventory and Analysis (FIA), for their helpful insight and valuable knowledge of US terrestrial ecological systems. In addition, Greg Dillon, Rocky Mountain Research Station, Fire Sciences Laboratory, provided useful discussion about the strengths and weaknesses of the Biophysical Settings (BPS) data product.

\section{LITERATURE CITED}

Archer, S., T. W. Boutton, and K. A. Hibbard. 2001. Trees in grasslands: biogeochemical consequences of woody plant expansion. In: E. D. Schulze, S. P. Harrison, M. Heimann, E. A. Holland, J. Lloyd, I. C. Prentice, and D. Schimel [EDS.]. Global biogeochemical cycles in the climate system. San Diego, CA, USA: Academic Press. p. 115-138.

Bechtold, W. A., and P. L. Patterson. 2005. The enhanced forest inventory and analysis program-national sampling design and estimation procedures. Asheville, NC, USA: US Department of Agriculture, Forest Service, Southern Research Station. General Technical Report SRS-80. 85 p.

Burkinshaw, A. M., And E. W. Bork. 2009. Shrub encroachment impacts the potential for multiple use conflicts on public land. Environmental Management 44:493-504.

Caratti, J. F. 2006. The LANDFIRE Reference Database. In: M. G. Rollins and C. K. Frame [EDS.]. The LANDFIRE Prototype Project: nationally consistent and locally relevant geospatial data and tools for wildland fire management. Fort Collins, CO, USA: US Department of Agriculture, Forest Service, Rocky Mountain Research Station. General Technical Report RMRS-GTR-175. 416 p.

Comer, P., D. Faber-Langendoen, R. Evans, S. Gawler, C. Josse, G. Kittel, S. Menard, M. Pyne, M. Reid, K. Schulz, K. Snow, and J. Teague. 2003. Ecological systems of the United States: a working classification of U.S. terrestrial systems. Arlington, VA, USA: NatureServe. 75 p.

Comer, P. J., and K. A. Schulz. 2007. Standardized ecological classification for mesoscale mapping in the southwestern United States. Rangeland Ecology \& Management 60:324-335.

[FGDC] Federal Geographic Data Committee. 2008. National vegetation classification standard, FGDC-STD-005-2008 (version 2). Reston, VA, USA: Vegetation Subcommittee, Federal Geographic Data Committee, FGDC Secretariat, US Geological Survey.

Grossman, D. H., D. Faber-Langendoen, A. S. Weakley, M. Anderson, P. S. Bourgeron, R. Crawford, K. Goodin, S. Landaal, K. Metzler, K. Patterson, M. Pyne, M. Reid, AND L. SNEDdon. 1998. International classification of ecological communities: terrestrial vegetation of the United States. Volume I. The National Vegetation Classification System: development, status, and applications. Arlington, VA, USA: The Nature Conservancy. $126 p$

Hunt, E. R., Jr., J. H. Everett, J. C. Ritchie, M. S. Moran, D. T. Booth, G. L. Anderson, P. E. Clark, and M. S. Seyfri. 2003. Applications and research using remote sensing for rangeland management. Photogrammetric Engineering \& Remote Sensing 69:675-693.

JOYCE, L. 1989. An analysis of the range forage situation in the United States: 1989-2040. A technical document supporting the 1989 US Department of Agriculture, Forest Service RPA Assessment. Fort Collins, CO, USA: US Department of Agriculture, Forest Service, Rocky Mountain Forest and Range Experimental Station. General Technical Report RM-GTR-180. 136 p. 
Joyce, L. A., J. E. Mitchell, and S. R. Loftin. 2000. The applicability of Montreal Process Criterion 3-maintenance of ecosystem health-to rangelands. International Journal of Sustainable Development and World Ecology 7:107-127.

Knapp, A. K., J. M. Briggs, S. L. Collins, S. R. Archer, M. S. Bret-Harte, B. E. Ewers, D. P. Peters, D. R. Young, G. R. Shaver, E. Pendall, and M. B. Cleary. 2008. Shrub encroachment in North American grasslands: shifts in growth form dominance rapidly alters control of ecosystem carbon inputs. Global Change Biology 14:615-623.

KnIGht, R. L., And P. B. Landres. 1998. Stewardship across boundaries. Covelo, CA, USA: Island Press. $371 \mathrm{p}$.

Lund, G. H. 2007. Accounting for the worlds rangelands. Rangelands 2:3-10.

MitcheLL, J. E. 2000. Rangeland resource trends in the United States. A technical document supporting the 2000 USDA Forest Service RPA Assessment. Fort Collins, C0, USA: US Department of Agriculture, Forest Service, Rocky Mountain Research Station. General Technical Report RMRS-GTR-68. 84 p.

Mitchell, J. E., L. A. Joyce, and L. D. Bryant. 1999. Applicability of Montreal Process criteria and indicators to rangelands. In: D. Eldridge and D. Freudenberger [EDS.]. Proceedings of the VI International Rangeland Congress; 23 July 1999; Townsville, Queensland. People and rangelands building the future: Australia. Volume 1. p. 183-185.

Mitchell, J. E., and T. C. RoberTs, Jr. 1999. Distribution of pinyon-juniper in the western United States. In: S. B. Monson and R. Stevens [comps.]. Proceedings: Ecology and Management of Pinyon-Juniper Communities within the Interior West. Fort Collins, CO, USA: US Department of Agriculture, Forest Service. RMRS-P-9. p. 146-154.

Nafus, A., M. P. McClaran, S. R. Archer, and H. L. Throop. 2008. Multi-species allometric models predict grass biomass in semi-desert rangeland. Rangeland Ecology \& Management 62:68-72.

[NRCS] Natural Resources Conservation Service. 1997. National range and pasture handbook. Washington, DC, USA: US Department of Agriculture, NRCS. Available at: http://www.glti.nrcs.usda.gov/technical/publications/nrph.html. Accessed 21 June 2011.

Nusser, S. M., F. J. Breidt, and W. A. Fuller. 1998. Design and estimation for investigating the dynamics of natural resources. Ecological Applications 8:234-245.

Nusser, S. M., And J. J. Goebel. 1997. The National Resources Inventory: a longterm multi-resource monitoring programme. Environmental and Ecological Statistics 4:181-204.

Reeves, M., K. C. Ryan, M. G. Roluins, and T. Thompson. 2009. Spatial fuel data products of the LANDFIRE Project. International Journal of Wildland Fire 18:250-267.

RoluINs, M. 2009. LANDFIRE: a nationally consistent vegetation, wildland fire and fuel assessment. International Journal of Wildland Fire 18:235-249.

Roth, A., S. Bunting, and E. Strand. 2010. Relationships between landscape patterns and fire occurrence within a successional gradient in sagebrush steppe/juniper woodland. International Journal of Wildland Fire 20:69-77.
Schmidt, K. S., J. P. Menakis, C. C. Hardy, W. J. Hann, and D. L. Bunnel. 2002. Development of the coarse-scale spatial data for wildland fire and fuel management. Fort Collins, CO, USA: US Department of Agriculture, Forest Service, Rocky Mountain Research Station. General Technical Report RMRS-GTR-87. 41 p.

Schuman, G. E., H. H. Janzen, and J. E. Herrick. 2002. Soil carbon dynamics and potential carbon sequestration by rangelands. Environmental Pollution 116:391-396.

Shinneman, D. J., AND W. L. BAKER. 2009. Environmental and climatic variables as potential drivers of post-fire cover of cheatgrass (Bromus tectorum) in seeded and unseeded semiarid ecosystems. International Journal of Wildland Fire 18:191-202.

Smith, W. B., P. D. Miles, J. S. Vissage, and S. A. Pugh. 2004. Forest resources of the United States, 2002. St. Paul, MN, USA: US Department of Agriculture, Forest Service, North Central Research Station. General Technical Report NRS-NC-241. $137 \mathrm{p}$.

Spreitzer, P. N. 1985. Transitory range: a new frontier. Rangelands 7:33-34.

[SRM] Society for Range Management. 1998. A glossary of terms used in range management. Denver, CO, USA: SRM. 20 p.

Steward, K. K., And W. H. ORnes. 1975. The autecology of sawgrass in the Florida everglades. Ecology 56:162-171.

[USDA] US Department of Agriculture, Forest Service. 2007. Forest Inventory and Analysis national core field guide, vol. I: field data collection procedures for phase 2 plots. Version 4.0. 224 p. Available at: http://www.fia.fs.fed.us/library/ field-guides-methods-proc/. Accessed 24 September, 2011.

[USDA] US Department of Agriculture, Forest Service. 2008. Field instructions for the annual inventory of California, Oregon and Washington. FIA Program, PNW Research Station, US Department of Agriculture, Forest Service. $348 \mathrm{p}$. Available at: http://www.fs.fed.us/pnw/fia/publications/fieldmanuals.shtml. Accessed 28 July 2010.

[USDA] US Department of Agriculture, Forest Service. 2010. Interior West Forest Inventory \& Analysis P2 field procedures. Washington, DC, USA: USDA. $370 \mathrm{p}$.

[USDA nRCS] US Department of Agriculture, Natural Resources Conservation SERVICE. 1997. National range and pasture handbook. Washington, DC, USA: USDA. $7 \mathrm{p}$.

[USDA] US Department of Agriculture, Soll Conservation Service. 1981. 26 ecological communities of Florida. Washington, DC, USA: USDA. $268 \mathrm{p}$.

Vogelman, J. E., S. M. Howard, L. Yang, C. R. Larson, B. K. Wylie, and J. N. Van Driel. 2001. Completion of the 1990s National Land Cover DataSet for the conterminous United States. Photogrammetric Engineering \& Remote Sensing 67:650-662.

Zhu, Z., D. Ohlen, J. Kost, X. Chen, and B. Tolk. 2006. Mapping existing vegetation composition and structure for the LANDFIRE prototype project. In: M. G. Rollins and C. K. Frame [EDS.]. The LANDFIRE prototype project: nationally consistent and locally relevant geospatial data and tools for wildland fire management. Fort Collins, CO, USA: US Department of Agriculture, Forest Service, Rocky Mountain Research Station. General Technical Report RMRSGTR-175. p. 197-215. 